\title{
Discussing death with the living
}

\author{
Ken Flegel MD MSc, Kirsten Patrick MB BCh DA
}

See also page 711 and www.cmaj.ca/lookup/doi/10.1503/cmaj.151171, and page E217 and www.cmaj.ca/lookup/doi/10.1503/cmaj.160206

$\mathrm{A}$ lthough conversations about how we die have become intense in Canada following the Supreme Court of Canada's ruling last year and the current legislative process, there is a curious lack of discussion about the existential fact that we will all die and how considering that fact might help us improve our lives. In an essay about a village located on the slope of an intermittently active volcano, Robert Louis Stevenson noted that the villagers seemed to live as though the volcano would not erupt. And he went on to argue that the rest of us live that way as well.

What happens after death is unknowable. But nothing is more certain than that each of us must die. Since we will die only once, we can only hope to do it well. Death and its finality give life its immediacy and, if we did but acknowledge it, immense meaning. It is urgent that we get on with life - yet often we live as though death did not exist.

To ask a patient if he or she is concerned with death, or about dying, seems more like a pastoral than a clinical question, heralding a conversation that we might prefer to avoid. But perhaps we are failing to keep up. People seem to want to talk about death. Careful consideration of death and mortality used to be the purview of the morbid, the depressed and teens with gothic leanings - but no more.

The now-global "Death Cafe" movement, begun in 2011, aims to "increase awareness of death with a view to helping people make the most of their (finite) lives." ${ }^{.1}$ At a Death Cafe event, people gather to eat cake, drink tea and discuss death. The many people in 33 countries who have attended more than 2700 events organized by this not-for-profit social franchise seem to have been convinced that having a conversation about death is a good idea. This global social movement has allowed talk of death to become mainstream and positive, a buttress to the living of a full life. So-called death education courses are now offered in some universities and medical schools.

Cancer care has progressed to the point where it is becoming normal for patients with, say, breast or prostate cancer to be told that death is unlikely to result from the disease. This growing optimism about cancer management may lead to less consideration for goals of care that include the eventuality of death. And so when a patient's cancer does not respond to treatment, the health care team may be confronted with a surprised and devastated patient and family. Urgent calls go out to the overstretched palliative care service. This gulf in perception - and the resulting gap in care - are our creations, and we must address them.

Patients have a lifelong relationship with health care providers and, as with any long relationship, it is helpful to build a strong foundation for its future. If asking patients how they feel and think about death seems too blunt, asking how they see life going from here can open the general topic as to how and when it might end. Talking freely and without euphemism about death with well patients allows us to identify the patient who is anxious about death.

For those patients who live as though death will never happen, talking about death allows us to introduce the concept of accumulated risk factors, the risk of a shorter life because of lifestyle choices - and the important notion of maximizing the length of disability-free life. For managing a particular disease episode, being able to say frankly that there is a real risk of death, or a real possibility for death avoidance with patient adherence to a plan of investigation or intervention, allows a shared plan that is more likely to meet the patient's own goals of care. And we may make headway in removing the gulf between curative care and palliative care.

A CMAJ study found that many patients and caregivers find the term "palliative care" distasteful, particularly if patients don't yet feel they are at the end of their lives. ${ }^{2}$ The author of a linked commentary preferred the use of the term "supportive care," to facilitate its early and personalized integration into disease management. ${ }^{3}$

Whether called palliative or supportive care, the practice of optimizing care so as to support a patient's goals for end of life should no longer be a practice set apart, but should become a part of ordinary medical practice. Physicians need to create a more relaxed atmosphere around the topic of death.

"Sister Death, from whose embrace no mortal can escape," as St. Francis so vividly put it, should be viewed not only as that dark night that beckons, but also as that final goal — one of accomplishment — to which all of life tends.

\section{References}

1. Death Cafe. What is Death Cafe? Available: http://deathcafe.com/what/\#sthash. JxwLdHH7.dpuf (accessed 2016 May 12).

2. Zimmerman C, Swami N, Krzyzanowska M, et al. Perceptions of palliative care among patients with advanced cancer and their caregivers. CMAJ 2016;188; E217-27.

3. Caprio AJ. Palliative care: renaming as supportive care and integration into comprehensive cancer care. CMAJ 2016;188:711-2.

Competing interests: See www.cmaj.ca/site/misc/cmaj_staff.xhtml.

Affiliations: Senior Editor (Flegel), Deputy Editor (Patrick), CMAJ

Correspondence to: CMAJ editor,pubs@cmaj.ca

CMAJ 2016. DOI:10.1503/cmaj.160547 